IRA-International Journal of Education \& Multidisciplinary Studies

ISSN 2455-2526; Vol.03, Issue 03 (2016)

Institute of Research Advances

http://research-advances.org/index.php/IJEMS

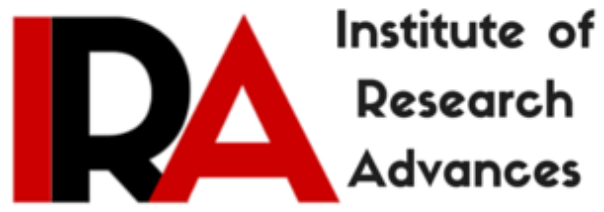

\title{
Peace Education Knowledge, Attitudes, Values and Skills (KAVS) of Pre-Service Teachers
}

Guiller P. Pendon

West Visayas State University-Janiuay Campus

Cabesa Jose D. Brana Street

Janiuay, Iloilo, Philippines

DOI: http://dx.doi.org/10.21013/jems.v3.n3.p5

\section{How to cite this paper:}

Pendon, G. (2016). Peace Education Knowledge, Attitudes, Values and Skills (KAVS) of Pre-Service Teachers. IRA International Journal of Education and Multidisciplinary Studies (ISSN 2455-2526), 3(3).

doi:http://dx.doi.org/10.21013/jems.v3.n3.p5

(C) Institute of Research Advances

\section{(cc) EY-NC}

This works is licensed under a Creative Commons Attribution-Non Commercial 4.0 International License subject to proper citation to the publication source of the work.

Disclaimer: The scholarly papers as reviewed and published by the Institute of Research Advances (IRA) are the views and opinions of their respective authors and are not the views or opinions of the IRA. The IRA disclaims of any harm or loss caused due to the published content to any party. 


\begin{abstract}
Pre-service teachers who were acquainted with the schemes of peace education can be an agent of transformation in the global society and must place peace education in their heart as future teachers. A sample of 80 students of WVSU-Janiuay Campus was chosen through stratified sampling. Data were gathered with the aid of peace education awareness questionnaire-checklist adapted from Castro \& Galace (2008). It utilized the descriptive design to collect, analyze and classify data on the level of awareness of the pre-service teachers on the Knowledge, Attitudes, Values and Skills (KAVS) schemas of peace education. The combined scores of pre-service teachers were aware of peace education's knowledge, attitudes, values and skills areas. When classified as to course, the BEED, were aware while the BSED were very aware. Both male and female were aware. Those with high grade point average were very aware while those with average and low grade point average were aware of the peace education schemas. As an entire group, the attitudes and values scores of the respondents were aware and when grouped according to course, it showed that all respondents were very aware. Both sexes were aware of peace education KAVS.
\end{abstract}

Keywords: attitudes, knowledge, peace education, Pre-Service Teachers, skills, values

For nearly five decades, educators were concerned with the problem of teaching peace, and have argued that education has an accountability to address the related issues through education in the school system, in the training of teachers, and in development of pedagogies which are related to the goals of peace. Peace education is a unifying and comprehensive concept that seeks to promote a holistic view of education (Castro \& Galace, 2008).

Given that peace education teachings and relevant trainings were absent from the curriculum content, it is assumed that the connections between relevant course content and the umbrella term of peace education were not made. Given that peace education serves to piece together a variety of teachings to achieve positive peace, the connection of the teachings held under this title need to be connected in a way that allows pre-service students to recognize these connections. This connection is currently absent from the curriculum, and therefore, the inclusion of peace education topics are not fulfilling their full potential (Galtung, 2003).

Today, choosing to teach peace education in one's class is only the first step to empower students to strive for a more peaceful society. In order to be successful, it is imperative that teachers recognize that this overarching goal must also be partnered with a medium through which learners can objectify and identify the peace education content.

The West Visayas State University-Janiuay Campus (WVSU-JC) is currently integrating peace education as one of the special topics to pre-service teachers for almost two years, however there was no baseline study conducted to ascertain the level of awareness of these pre-service teachers on peace education areas; knowledge, attitudes, values and skills.

For several years, most pre-service teachers at WVSU-JC voiced out during feedbacking hours that they were beset by many learning problems like handling learners' diversities, addressing conflicts among learners, building value-laden learners, and maintaining a peaceful classroom. Looking at these concerns, a need 
emerged to generate a baseline survey in order to underscore the important areas in peace education to be given most priority and for further studies to be developed in the future based on the result of this current study.

This study was anchored on the peace concepts, ideas and perspectives embodied in Castro and Galace's (2008) book entitled: Peace Education: A Pathway to a Culture of Peace. As postulated by the authors, the holistic definition of peace is to think of peace as not only an absence of direct violence but also the presence of the conditions of wellbeing.

The current study is founded on the theory of transformative education. For education to be transformative, it needs a safe and supportive environment in which a learning space can be created to enable learners to confront chaos, pain, fears and bewilderedness. Within a safe environment, learners are free from judgment, bullying, negative conflicts and intimidation, so that they can be courageous enough to be pushed to the boundaries of their realities. Hence, learners are more likely to discover all aspects of themselves and develop as whole-persons.

It is believed that education is essentially about the promotion of personhood and the development of full human potential. While we are confronted by the challenges of different social and educational systems, transformative education may play a big part in helping individuals to become truly human beings. By this, we also mean individuals' development as whole-persons - the development in all aspects of a human being, including the physical, moral, creative, emotional, intellectual and spiritual; as well as the expression of their potential.

For transformation to be the goal, it involves the intention from both policy and institutional level as well as the intentional efforts from the individuals themselves. Learners need to show willingness to embrace the challenges throughout the process of change (Mezirow, 2000). This can be achieved through education thus, peace education must be part of this process.

Peace education, not merely just a movement but a theory itself is an education that promotes the culture of peace, is essentially transformative. It cultivates the knowledge base, skills, attitudes and values that seek to transform people's mindsets, attitudes and behaviors that in the first place, have either created or exacerbated violent conflicts. It seeks this transformation by building awareness, developing concern and challenging personal and social action that will enable people to live, relates and creates conditions and systems that actualize non-violence, justice, environmental care and other peace values (Castro \& Galace, 2008).

In the light of the aforementioned literatures, the pre-service teachers must be trained on how to make teaching and learning in their classrooms consensual and to establish good rapport among their co-student teachers and cooperating teachers using the knowledge, attitudes, values and skills of peace education.

This study aimed at ascertaining the awareness on Peace Education knowledge, attitudes, values and skills of the pre-service teachers enrolled during SY 2012-2013 at West Visayas State University-Janiuay Campus.

Specifically, this study sought answers to the following questions:

1. What is the level of awareness of pre-service teachers on the peace education knowledge, attitudes, values and skills when taken as an entire group and grouped according to course, sex and grade point average? 
2. Is there a significant difference on the awareness of pre-service teachers on the peace education knowledge, attitudes, values and skills when taken as an entire group and when grouped according to course, sex and grade point average?

\section{Methodology}

The Peace Education KAVS relies on analyzing the different contexts of society and needs related to the integration of peace education towards change in human behavior and teaching strategies to be utilized in the classroom as pre-service teachers. The study made reference to the specific situations and needs of the learners in the school, the research required for a more in-depth analysis of the possibilities for integrating positive values.

Thus, this study utilized the descriptive design to collect, analyze and classify data on the level of awareness of the pre-service teachers on peace education knowledge, attitudes, values and skills. Respondents were gathered in campus function hall and the researcher gave an initial orientation as to how research instrument will be answered and clearly discussed the content of the instrument. For almost one hour the respondents carefully answered various questions on the schemas of peace education then the researcher gathered the accomplished instruments as soon as the respondents finish answering them.

The answers of the pre-service teachers in the awareness questionnaire checklist were used as the basis in determining the level of awareness on peace education knowledge, attitudes, values and skills areas. The data obtained from this investigation were tallied, computer processed, analyzed and interpreted.

\section{Respondents}

As the initial step, the researcher identified who are duly enrolled pre-service teachers for the second semester SY 2012-2013. Identification of student-respondents was based on the course, sex and grade point average.

There were 80 respondents who are the pre-service teachers of West Visayas State University-Janiuay Campus. These respondents were classified into course, sex and grade point average. As to course, $75 \%(\mathrm{n}=60)$ were Bachelor in Elementary Education (BEED), while $25 \%(\mathrm{n}=20)$ were Bachelor in Secondary Education (BSED). As to sex, $82.5 \%(n=66)$ were females and $17.5 \%(n=14)$ were males. When classified as to GPA, respondents or $12.5 \%(\mathrm{n}=10)$ had high GPA, $77.5 \%$ $(n=62)$ had average GPA and $10 \%(n=8)$ had low GPA.

\section{Research Instrument}

The tentative draft of the questionnaire was submitted for validation to a panel of jurors who are expert in the field of peace education. After the questionnaire was revised and finalized, permission to conduct the study was secured from the campus administrator and the instrument was distributed to pre-service teachers at West Visayas State University-Janiuay Campus

The data-gathering instrument that was used in the study was an awareness questionnaire -checklist adapted from (Castro and Galace, 2008) however, minimal modifications were made after it was reviewed by the panel of experts.

The instrument consists of two parts. Part One, requires of personal data such as name, course, sex, and GPA. Part Two is the instrument proper which contains forty-five (45) item statements from the respondents' level of awareness on peace education knowledge, attitudes, values and skills. Twenty three (23) items comprise 
the knowledge area, twelve (12) items on the attitudes and values and Ten (10) items on the skills area.

A copy of the instrument is found in Appendix A.

The researcher constructed a rating scale designed to determine the level of awareness of pre-service teachers on peace education knowledge, attitudes, values and skills areas.The five levels to be determined were unaware, somewhat aware, aware, very aware and extremely aware.

"Unaware" means that the respondents were not familiar on concepts on peace education knowledge, attitudes, values and skills areas.

"Somewhat aware" means that the respondents have very little familiarity on concepts on peace education knowledge, attitudes, values and skills areas.

"Aware" means that the respondents have high familiarity on concepts on peace education knowledge, attitudes, values and skills areas.

"Very aware" means that the respondents have higher familiarity on concepts on peace education knowledge, attitudes, values and skills areas.

"Extremely Aware" means that the respondents have the highest familiarity on concepts on peace education knowledge, attitudes, values and skills areas.

In determining the results an arbitrary scale was used:

Scale of Mean

$1.0-1.80$

$1.81-2.60$

$2.61-3.40$

$3.41-4.20$

$4.21-5.00$
Description

Unaware

Somewhat Aware

Aware

Very Aware

Extremely Aware

\section{Results}

Table 1 showed that the pre-service teachers when taken as an entire group were aware of peace education, knowledge, attitudes, values and skills. When classified as to course, the BEED pre-service teachers were aware while BSED preservice teachers were very aware. When classified as to sex, both males and females were aware. When classified as to grade point average, those with high GPA were very aware, while those with average GPA and those with low were aware.

Table 1

Means and Standard Deviations of Peace Education Scores of Pre-service Teachers when Taken as an Entire Group, and Grouped According to Course, Sex, and Grade Point Average (GPA)

\begin{tabular}{llll}
\hline Categories & SD & Mean & Description \\
\hline $\begin{array}{l}\text { Entire Group } \\
\text { Course }\end{array}$ & .52 & 3.38 & Aware \\
$\quad$ BEED & .50 & 3.27 & Aware \\
$\quad$ BSED & .46 & 3.70 & Very Aware \\
Sex & & & \\
$\quad$ Male & .43 & 3.37 & Aware \\
Female & .54 & 3.38 & Aware
\end{tabular}


GPA

\begin{tabular}{llll} 
High & .35 & 3.47 & Very Aware \\
Average & .54 & 3.39 & Aware \\
Low & .60 & 3.22 & Aware \\
\hline
\end{tabular}

The data in Table 2 showed that when taken as an entire group, the preservice teachers were aware on knowledge area of peace education. When classified as to course, the BEED were aware while the BSED were very aware. When classified as to sex, both sexes were aware. When classified as to GPA, the respondents in all categories were aware.

Table 2

Means and Standard Deviations of Knowledge Scores of Pre-service Teachers Taken as an Entire Group and Grouped According to Course, Sex and GPA

\begin{tabular}{llll}
\hline Categories & Mean & $S D$ & Description \\
\hline Entire Group & 3.25 & .52 & Aware \\
Course & & & \\
$\quad$ BEED & 3.16 & .50 & Aware \\
BSED & 3.53 & .50 & Very Aware \\
Sex & & & \\
$\quad$ Male & 3.21 & .38 & Aware \\
Female & 3.27 & .55 & Aware \\
GPA & & & \\
$\quad$ High & 3.36 & .32 & Aware \\
Average & 3.25 & .54 & Aware \\
Low & 3.13 & .58 & Aware \\
\hline
\end{tabular}

The data in Table 3 showed that when taken as an entire group, the preservice teachers were very aware on attitudes and values areas of peace education. When classified as to course, both courses were very aware. When classified as to sex, both sexes were very aware. When classified as to GPA, the respondents who have high GPA and average GPA were very aware, while those with low GPA were aware.

Table 3

Means and Standard Deviations of Attitudes and Values Scores of Pre-service Teachers when Taken as an Entire Group and when Grouped According to Course, Sex and GPA

\begin{tabular}{lllc}
\hline Categories & Mean & SD & Description \\
\hline Entire Group & 3.56 & .58 & Aware \\
Course & & & \\
BEED & 3.44 & .57 & Very Aware \\
BSED & 3.88 & .50 & Very Aware \\
Sex & & & \\
$\quad$ Male & 3.55 & .58 & Very Aware \\
Female & 3.56 & .59 & Very Aware \\
GPA & & & \\
High & 3.62 & .47 & Very Aware \\
Average & 3.58 & .59 & Very Aware \\
Low & 3.28 & .65 & Aware \\
\hline
\end{tabular}


The data in Table 4 showed that when taken as an entire group, the preservice teachers were very aware on skills area of peace education. When classified as to course, the BEED were aware while BSED were very aware. When classified as to sex, both males and females were very aware. When classified as to GPA, the respondents who have high GPA and average GPA were very aware, while those with low GPA were aware.

Table 4

Means and Standard Deviations of Skills Scores of Pre-service Teachers when Taken as an Entire Group and Grouped According to Course, Sex and GPA

\begin{tabular}{llll}
\hline Categories & Mean & SD & Description \\
\hline $\begin{array}{l}\text { Entire Group } \\
\text { Course }\end{array}$ & 3.46 & .64 & Very Aware \\
$\quad$ BEED & 3.32 & .59 & Aware \\
BSED & 3.88 & .62 & Very Aware \\
Sex & & & \\
$\quad$ Male & 3.51 & .53 & Very Aware \\
Female & 3.45 & .66 & Very Aware \\
GPA & & & \\
High & 3.53 & .44 & Very Aware \\
Average & 3.46 & .66 & Very Aware \\
Low & 3.36 & .70 & Aware \\
\hline
\end{tabular}

\section{Inferential Data Analysis}

The t-test for independent samples was used to determine the significance of difference in level of awareness on peace education knowledge, attitudes, values and skills of pre-service teachers when classified as to course.

The data in Table 5 showed that there was a significant difference in the level of awareness on peace education knowledge, attitudes, values and skills between the BEED and BSED pre-service teachers $(\mathrm{t}=3.40, \mathrm{p}<.05)$. Therefore, the first null hypothesis was rejected.

The result contradicts the awareness study of Garcia (2000) and Sulleza (2007) were the respondents did not show any significant difference on their level of awareness.

However, the study of Tapper (2007) which used the course or degree programs as one of the variables on students' awareness of how critical thinking is embedded in a degree program, agrees with the view that one's course may influence one's level of awareness.

Furthermore, the studies of Schweitzer (2010), Reed and Wilson (2005), and McDermorth, Moore, et. al (2006) also seem to support the same thought. It is notable that none of the local studies reviewed matched the results of the present study. 
Table 5

t-test for Independent Samples for Significance of Difference in Level of Awareness on Peace Education Knowledge, Attitudes, Values and Skills of Pre-Service Teachers when Classified as to Course

\begin{tabular}{lccccc}
\hline Categories & Mean & Mean Difference & $d f$ & $t$ & Sig.(2-tailed) \\
\hline BEED & 3.70 & .43 & 78 & $3.40^{*}$ & .001 \\
BSED & 3.27 & & & & \\
\hline
\end{tabular}

$* \mathrm{p}<.05$, Significant

The t-test for independent samples was used to determine the significance of difference in the level of awareness on peace education knowledge, attitudes, values and skills of pre-service teachers when classified as to sex.

The data in Table 6 showed that there was no significant difference in the level of awareness on peace education knowledge, attitudes, values and skills between the males and females $(\mathrm{t}=-.11, \mathrm{p}>.05)$. Therefore, the second null hypothesis was accepted.

The studies of Velez (1998), Asan (2005) and Markova, et. al (2003) contradict the result of this study because it showed a significant difference on the awareness level of the respondents when classified as to sex.

There is one study that conforms to the result, and this is the study of Watson (2003) wherein no significant difference existed on the level of awareness of the respondents when classified as to sex.

Table 6

t-test for Independent Samples for Significance of Difference in Level of Awareness on Peace Education Knowledge, Attitudes, Values and Skills of Pre-Service Teachers when Classified as to Sex

\begin{tabular}{lrcccc}
\hline Categories & Mean & Mean Difference & $d f$ & $t$ & Sig.(2-tailed) \\
\hline Males & 3.37 & 01 & 78 & -.11 & .91 \\
Females & 3.38 & & & &
\end{tabular}

The one-way Analysis of Variance (ANOVA) was used to determine the significance of difference in the level of awareness on peace education knowledge, attitudes, values and skills of pre-service teachers when classified as to GPA.

The data in Table 7 showed that there is no significant difference in the level of awareness on peace education knowledge, attitudes, values and skills of preservice teachers when classified as to GPA $(\mathrm{F}=.51, \mathrm{p}>.05)$.

The study of Prudente (2006) seems to support the same thought of the present study when grade point average (GPA) was used as one of the variables.

However, the study of Raphael (2001) contradicts the result of the current study when GPA was used as one of the research variables

Thus, the third null hypothesis is accepted. 
Table 7

One-Way ANOVA Result for Significance of Difference in Level of Awareness on

Peace Education Knowledge, Attitudes, Values and Skills of Pre-Service Teachers when Classified as to GPA

\begin{tabular}{lccccc}
\hline Source of Variation & Sum of Squares & $d f$ & Mean Square & $F$ & Sig \\
\hline Between Groups & .28 & 2 & .14 & .51 & .60 \\
Within Groups & 21.26 & 77 & .28 & & \\
Total & 21.5 & 79 & & & \\
& & & & & \\
\hline
\end{tabular}

When taken as an entire group, the BEED and BSEd pre-service teachers were aware of peace education knowledge, attitudes, values and skills areas, and when classified as to course the BEED were aware while the BSED were very aware. As to sex both male and female were aware. As to grade point average (GPA); high GPA were very aware while those with average and low GPA were aware of the peace education KAVS.

Reardon (1988) maintains that combining knowledge, skills and attitudes is perhaps desired in the field at this time. She sees peace education as a process that prepares young people for global responsibility; enables them to understand the nature and implications of global interdependence. This result is encompassing since in hindsight, this is what many programs ultimately want to achieve.

When taken as an entire group on knowledge scores of peace education the BEED and BSED pre-service teachers were aware and when classified as to course, it showed that the BEED were aware while the BSED were very aware. When classified as to sex, both males and females were aware and when classified as to GPA the respondents were aware.

Again, these are encompassing notes since Castro \& Galace (2008) think that in today's world, more so, a knowledge on a culture of peace should be seen as the essence of new humanity, a new global civilization based on inner oneness and outer diversity and the flourishing of culture of peace will generate the mindset in us that it is prerequisite for the transition from force to reason, from conflict and violence to dialogue and peace.

When taken as an entire group, the attitudes and values scores of the respondents were very aware. When grouped according to course, it showed that BEED and BSED were very aware. When classified as to sex, both male and female were very aware and when classified as to GPA those with high and average GPA were very aware and those with low GPA were aware.

A new way of thinking about peace is so important today. The power of our own understanding and views of peace both as a condition and as a value cannot be underestimated. It is because our ideas shape our feelings and our actions as well as how we live and how we relate with others. For this reason, Capra (1982) in his widely acclaimed book, "The Turning Point", has argued for the need for a change in thinking, about both concepts and values, as a necessary first step to solve our many problems today (Capra, 1982).

When taken as an entire group, the skills scores of pre-service teachers were very aware. When grouped as to course, the BEED were aware while BSED were very aware. When classified as to sex, both male and female were very aware and 
when classified as to GPA, those with high and low GPA were very aware and those with low GPA were aware.

As mentioned by Castro \& Galace (2008), never it has been important for the males or females of the new generation to learn about the world and understand its diversity. The task of educating children of peace education skills is of primary importance. All educational institutions need to offer opportunities that prepare the students not only to live fulfilling lives but also to be responsible and productive citizens of the world. Skills can be taught and learned thus peace education can work for the furtherance of its agenda by specifying learners with needed skills.

It also showed that there was a significant difference in the level of awareness on peace education knowledge, attitudes, values and skills when respondents were classified as to course and no significant difference when they were classified as to sex and GPA.

This can be inferred to the idea that to facilitate the topics of peace education through peaceful teaching methods is critical. It is a necessity to explore with both student teachers and in-service teachers the conceptual frameworks of peace education and methods for including peace education in their classrooms. Peace education will be productive when the theory and practice gap is successfully bridged (Laing, 2001).

When classified as to course, the BEED and BSED pre-service teachers differ significantly in the level of awareness on peace education knowledge, attitudes, values and skills.

This may suggest that there maybe some differences either in content or experience of the learners under these two programs because of the varying levels of awareness.

This could be related to the discussion in the work of Zine (2001) on the importance of peace education to the Bachelor of Education programs, to teach them to advocate for students the culture of peace. It was noted that the inclusion of these tests in Philosophy benefited the Bachelor of Education students who have gained some perspective on the amount of work required of teachers to gain the skills and attitudes to address and defeat racism and inequality in their classrooms. These are pretty much sure of the advocacies of peace education.

When classified as to sex, male and female pre-service teachers do not differ significantly in the level of awareness on peace education knowledge, attitudes, values and skills.

This is in conformity with the discussion made by the Inter-Agency Network for education in Emergencies (2006) which stated that despite this, women's individual and collective contributions to peace-building processes are frequently under-utilized. The inclusion of both sexes in every aspect of peace building is of critical importance because such measures: Building peace means engaging women as well as men in the process of resolving conflict, rebuilding institutions and society, and achieving sustainable peace.

Following also the rise of popular feminism and in keeping with the social justice movement of the late 1960's and onwards, efforts to oppose sexism in schools have been taken and over reaching goal is to enable students to reach their full potential regardless of their gender (Moser, 2005). Gender-Fair Education (GFE) 
seeks to foster among learners respect for the abilities and rights of both sexes to develop awareness of the gender biases and stereotyping that have culturally perpetuated in order to change these.

When classified as to grade point average (GPA), pre-service teachers with high, average and low GPA do not differ significantly in the level of awareness on peace education knowledge, attitudes, values and skills.

Despite of Hiemstra \& Sisco's (1990) contention that students' performance is determined by his or her course or degree on the concepts and factors of peace education, the local faculty members may be assured that students from across the academic achievement spectrum are aware of peace education and therefore, maybe able to integrate in their practice.

\section{Conclusions}

In view of the findings, the following conclusions were deduced.

The study proves that BSED students are better prepared to integrate peace education KAVS in their practice. Perhaps the curricular content and the teachinglearning experiences provided for BSED were comprehensive. The specialized training given in this academic program can be seen as a contributing factor to the increasing awareness of BSED students. On the other hand, BEED students must be given integrative and inclusive trainings to improve their awareness on peace education and apply the same in their field of practice.

It is proven that regardless of sex, anybody can have the full potential to be aware of peace education KAVS. There must be gender equality wherein both males and females be given maximum opportunity to embrace the culture of peace. There must be no bias outlook on the work of males and females, it means that both have the capacity to work and advocate for peace. Another, there must be no boundaries set as to grade point average because regardless of academic standing, the awareness for peace education is for all and it will never vary as long as the person has the passion and willingness to understand the culture of peace.

\section{Implication for Theory and Practice}

Peace Education is essentially, transformative education. It cultivates the knowledge base, skills, attitudes and values that seek to transform people's mindsets, attitudes and behaviors that in the first place, have either created or exacerbated violent conflicts. It seeks this transformation by building awareness and understanding, cultivating concern and challenging personal and social action that will enable people to live, relates and creates conditions and systems that actualize nonviolence, justice, environmental care and other peace values.

A careful review of current thought on the awareness of pre-service teachers shows that certain basic assumptions form the foundation of most existing theories with regard to the phenomena of human conflict in all its varied expressionsintrapersonal, interpersonal, and intergroup. The West Visayas State UniversityJaniuay Campus pre-service teachers must consider in the content subjects interpersonal/intergroup power-struggle and intense competition as necessary and inevitable life processes; and deem conflict the unavoidable outcome of this struggle. Teachers must work to decrease the destructiveness of human conflict and develop tools to resolve conflicts before they turn into aggression and violence. Within this overriding prominence accorded to "conflict" in most peace-related theories and action, there have been notable efforts on the part of various researchers and practitioners to offset the unavoidable negative consequences of conflict. 
It is recommended that the creation of realistic and workable peace education program must be given emphasis by most tertiary education institutions to address the needs and concerns of teachers, faculty, staff, students and community for a culture of peace. A program proposal to this effect is found in Appendix B of this study.

Peace Education Training must be done regularly to create a strong advocacy building against war and violence, and addressing adversaries because of individual difference.

In depth and thorough discussion on peace education knowledge, attitudes, values and skills must be interpreted especially in the special topic classes of preservice teachers or whenever possible.

Revision of the curriculum be made to include peace education as a content subject for the BSED and BEED programs. The inclusion of knowledge, attitudes, values and skills of peace education as a subject will enhanced students understanding of their roles as future peace educators.

Collaborations with Higher Educational Institutions in order to establish center for peace education that can immediately answer the needs and concerns related to the cultivation of the culture of peace.

Further researches must be conducted in order to widen the perspectives along this line. If possible, variables not being studied must be taken into account to make this study more comprehensive and other dimensions of peace education must also be explained by future researchers.

\section{References}

Asan, A., (2005), Computer Technology Awareness by Elementary School Teachers: A Case

Study from Turkey, Journal of Information Technology Education, Vol. 2, pp. 201-203.

Banta, B. (1993). Peaceful Peoples: An Annotated Bibliography. Metuchen, N.J: Scarecrow Press.

Capra, F. (1982). The turning point. Toronto: Bantam Books.

Castro \& Galace (2008). Peace education: A pathway to a culture of peace. Center for Peace Education, Miriam College, Quezon City,Philippines.

Garcia, F. (2000). Awareness on social studies program in public secondary schools in bacolod city: An evaluation (Unpublished Doctoral dissertation). WVSU, Iloilo City.

Galtung, J. (2003). Peace education (p. 223). London : McFarland \& Company, Inc., Publishers.

Hiemstra, R. \& Sisco, B (1990). Individualizing instruction. San Francisco : JosseyBass.

Laing, R.D. (2001). Learning the way of peace: A teachers guide to peace education,p. 4. New Delhi

McDermoth, R.,Hawkins, M., Moore, J., \& Cittadino, S., (2006), Aids awareness and information sources among selected university students. ( $5^{\text {th }}$ edition). Journal of American College Health, Vol. 35. pp. 222-226.

Mezirow, J. \& Associates (2000). Learning as transformation. Teacher's College, Columbia University.

Moser, A. (2005). Supporting women's active role in peace-building: issues, lessons national council of educational research and training.. Retrieved December 12, 2011 from http://www. ncert. nic.in/html/education 
Prudente, R. (2006). Knowledge and attitudes towards human sexuality: Basis for the development of guidance program in sex education. (Unpublished Doctoral dissertation). WVSU, Iloilo City.

Raphael, T., (2001), Increasing students' awareness of sources of information for answering questions. Michigan State University, Vol. 2. pp. 210-256.

Reardon, B. (1988) Comprehensive peace education: Educating for global responsibility. New York: Teachers College Press.

Reed, J. \& Wilson D. (2005). Awareness and use of a university recreational trail . Journal of American College Health, ( $4^{\text {th }}$ edition) Vol. 54. pp. 227-230.

Sulleza, G. (2007). Students' awareness, availment and understanding of the guidance Services of ST. Therese MTC College. (Unpublished Master's thesis). WVSU, Iloilo City.

Schweitzer, R. (2010) Problems and awareness of support services among students at an urban australian university. Journal of American College Health, $\left(2^{\text {nd }}\right.$. Edition) 73-77, Vol. 45.

Tapper, J., (2007), Students' awareness of how critical thinking is embedded in a degree program. Journal of American Education, Vol. 3. pp.199-222.

Velez, C. (1998). Awareness on self-concept, peer relationships and assertiveness among students in State Educational Institution in Iloilo. (Unpublished Doctoral dissertation). WVSU, Iloilo City

Watson, G. (2005). Pre-service teachers' views on their information technology education. Journal of Information Technology Education, Griffith University, Australia, Vol. 2

Zine, J. (2001). Negotiating equity: The dynamics of minority community engagement in constructing inclusive educational policy. Cambridge Journal of Education, 31(2): pp. 239-269. 